\title{
Identification of skin phototypes through in vivo photoacoustic measurements
}

\author{
Jociely Parrilha Mota, Jorge Luis Costa Carvalho, Paulo Roxo Barja*
}

\begin{abstract}
The aim of the present work was to classify and identify skin phototypes through in vivo photoacoustic (PA) measurements. Fifty-seven female volunteers took part in the study, being clinically evaluated and classified according to skin phototype (Fitzpatrick classification). After cleaning the skin area to be measured, the PA signal level was obtained for the inner and outer faces of both forearms. Volunteers were then classified according to the respective PA signal amplitude; subsequently, this classification was compared to the phototype classification and to the recently proposed Baumann classification. Comparison between the PA signal of the inner and outer faces of the forearm shows a highly significant statistical difference $(p<0.005)$, attributed to the higher pigmentation level of the skin region continuously exposed to solar radiation, demonstrating that skin constitution and aspect are influenced by the level of sun exposure. Comparison among phototypes was performed separately for the inner and outer faces of the forearm. The results show that the PA signal level (amplitude) for the inner forearm tends to scale with skin phototype, also allowing the division of the volunteers in two groups, according to their pigmentation levels and also following the recent Baumann classification. In this way, the photoacoustic methodology presented allows an objective, numerical classification of the skin types.
\end{abstract}

Keywords Skin, In vivo research, Photoacoustic technique, Phototype, Skin pigmentation.

\section{Identificação dos fototipos de pele através de medidas fotoacústicas in vivo}

Resumo O objetivo do presente trabalho foi de identificar e classificar os fototipos de pele através de mensurações fotoacústicas (PA) utilizada para caracterizar a pele em função da amplitude do sinal observado in vivo. Participaram do estudo cinquenta e sete mulheres voluntárias que incialmente foram avaliadas e classificadas de acordo com o fototipo da pele (classificação de Fritzpatrick). Foram realizadas medidas nas regiões interna e externa de ambos os antebraços, após a limpeza do mesmo com álcool 70\%. As voluntárias foram classificadas de acordo com o sinal fotoacústico, em seguida comparados com a classificação proposta recentemente por Baumann. A comparação entre o sinal PA das faces interna e externa do antebraço mostra uma diferença altamente significativa $(p<0,005)$, atribuida ao maior nível de pigmentação da pele da região continuamente expostos à radiação solar, demonstrando que a constituição do aspecto da pele é influenciada pelo nível de exposição ao sol. A comparação entre os fototipos foi realizada separadamente para as faces interna e externa do antebraço. Os resultados mostram que o nível (amplitude) do sinal PA para a parte interna do antebraço tende a seguir a classificação em fototipos, permitindo também a divisão de voluntários em dois grupos, conforme o nivel de pigmentação, seguindo assim a classificação recentemente proposta por Baumann. Assim, a metodologia fotoacústica apresentada permite uma classificação objetiva, numérica, dos tipos de pele.

Palavras-chave Pele humana, Medidas in vivo, Fotoacústica, Fototipos, Pigmentação. 


\section{Introduction}

The human skin comprises about $20 \%$ of the total human weight and has a number of functions, such as protection against environment agents, sensorial perception and regulation of body temperature. The melanocytes are the cells responsible by the production of the melanin pigment, an endogenous filter against ultraviolet (UV) radiation. Skin color depends on several factors, as the concentration of pigments in the skin. Epidermal and dermal cells give a natural white or yellow tonality (depending on thickness) to skin, but blood vessels also present a (primarily red) contribution to skin color, due to hemoglobin. However, skin pigmentation depends mainly on the level and localization of synthesized melanin, a proteic polymer (Gonchoroski and Corrêa, 2005; Viglioglia, 1991). UVA radiation promotes the oxidation of melanin precursors, leading to pigmentation without erithema, while UVB radiation generates indirect pigmentation, increasing the number of active melanocytes and producing erithema (sunburn) and even cancer lesions (Nicoletti et al., 2002). Increased production of melanin is a physiological response to solar radiation. Besides promoting skin coloration, melanin acts as a sunscreen; it absorbs, diffracts and reflects light, but absorption plays a major role in promoting skin photo protection (Giacomoni, 1995).

Skin color varies with race and according to the region of the body, being influenced by the environment. Skin color can be classified as constitutive (controlled by genetic factors) or facultative (depending on the level of sun exposition, hormonal characteristics and age) (Braunwald and Isselbacher, 1998). Continued exposition to UV radiation determines a thicker skin, with yellow-grey coloration.

In 1976, Fitzpatrick classified human skin in six types, from phototype I (white skin) to VI (black), according to the erithemic response and pigmentation level (Diffey, 2001). However, even being widely employed, the validity and reliability of the Fitzpatrick classification is still in controversy; there is no universal agreement about the best method for classifying skin (Kawada, 2000). As this classification method was based in clinical, subjective analysis, different techniques have been proposed to perform quantitative skin type evaluation; among them, the photoacoustic (PA) technique (Viator et al., 2004).

The photoacoustic (PA) effect was discovered by Graham Bell in 1880, when he observed that the incidence of modulated light on a solid sample produced sound (Cahen et al., 1980). The PA effect consists in the generation of acoustic waves as a result of the absorption of radiation. Through the generation of thermal or acoustic waves, one can obtain information about physical properties of materials such as elasticity, temperature, thermal diffusivity and effusivity, among others (Rosencwaig and Gersho, 1976). The use of the PA technique in dermatology began in 1977 with Rosencwaig; the studies involving the application of cosmetics began the following year (Bernengo et al., 1988).

It is a complex task to characterize organic tissues through conventional optical techniques, because such tissues normally present high light scattering (Carvalho et al., 2009); however, this is not a problem for photoacoustic (PA) measurements, in which the signal is based in the direct absorption of radiation. PA measurements can be employed to determine the absorption characteristics of the skin itself or topically applied products, as well as kinetic changes related to transdermal drug delivery.

Skin diseases can also be studied through PA measurements. Recently, a PA methodology was developed to determine the nature of skin lesions in vivo. Swearingen et al. (2010) irradiated skin with two laser wavelengths (422 and $530 \mathrm{~nm}$ ), with the relative response at these two wavelengths indicating if the lesion is pigmented or vascular, due to the distinct absorption spectrum of melanin and hemoglobin.

In 2004, Viator et al. proposed a method for the determination of the epidermal melanin content employing a PA probe using a Nd:YAG laser at $532 \mathrm{~nm}$ (Viator et al., 2004). Ten human subjects with skin phototypes I-VI were tested using the PA probe and visible reflectance spectroscopy (VRS); melanin content was evaluated through each of these methods, and a good linear fit $\left(r^{2}=0.85\right)$ was obtained for the plot of PA $\times$ VRS.

Pigmentation skin level can also be evaluated through simple, direct PA measurements employing non-laser light sources. In 2005, Sousa et al. used photoacoustic (PA) measurements to classify volunteers in two groups, according to their skin pigmentation level. The PA technique can also be employed to obtain the skin absorption spectra, as seen on Rompe et al. (2005) and Taube et al. (2008).

In this work, the PA technique was utilized to evaluate a larger sample, analyzing it with respect to phototypes (Fitzpatrick classification) and also identifying two groups of volunteers according to skin pigmentation level (Baumann classification).

\section{Materials and Methods}

\section{Ethical concerns}

The study was approved by the ethics committee in search of Univap through the protocol number L177/2005/CEP, following the rules with 
the authorization of the participants that signed the informed consent form.

\section{Experimental setup}

The PA setup consisted of a $250 \mathrm{~W}$ tungsten halogen lamp as light source, a chopper (SRS, model SR540), a lock-in amplifier (SRS, model SR530), a microcomputer for data acquisition and a double faced PA cell. Light fluence rate was about $20 \mathrm{~W} / \mathrm{m}^{2}$. The PA cell, with an electret microphone, was developed at the UNIVAP (Universidade do Vale do Paraíba); sensitivity was $50 \mathrm{mV} / \mathrm{Pa}$ at $100 \mathrm{~Hz}$ (about $15 \mathrm{mV} / \mathrm{Pa}$ for the frequency employed in this study). The electret microphone structure was described by Marquezini et al. (1991). The microphone is composed by a metalized electret diaphragm (10 $\mu \mathrm{m}$ thick, with a 50-100 nm thick deposited metallic film) and a metal plate separated from the diaphragm by a $45 \mu \mathrm{m}$ air layer. The entrance slit has a diameter of $3 \mathrm{~mm}$, and the internal chamber presents a diameter of $7 \mathrm{~mm}$ and a thickness of $1 \mathrm{~mm}$. The PA cell has a cylindrical body and two opposite, parallel faces: one is closed by a thin glass layer, while the sample itself closes the opposite face. Total air volume inside the PA cell is $317 \mathrm{~mm}^{3}$ (chamber + internal duct, $1 \mathrm{~mm}$ diameter) (Paiva and Barja, 2006). Figure 1 shows a diagram of the double faced PA cell employed.

\section{Photoacoustic measurements}

Light was modulated at $17 \mathrm{~Hz}$ and measurements were recorded as a function of time (for each measurement, 200 direct readings of the lock-in signal, 2 readings/s). During measurements, one face of the PA cell was closed with a thin glass window, while the forearm of the volunteer was gently pressed against the opposite face (see Figure 2).

For the modulation frequency employed, the thermal diffusion length of the skin is $30 \mu \mathrm{m}$, so the PA signal corresponds to an external skin layer of this thickness - essentially, the stratum corneum layer (Barja et al., 2005). Under these conditions, melanin contribution for the PA signal is much more important than the contribution of hemoglobin (actually, hemoglobin contribution could be an issue in volunteers with obstructed arterial condition, in which hemoglobin could be released from obstruction, maybe reaching the skin layer under study (Arkin et al., 2004).

Measurements were performed in 57 volunteers, female, between 20 and 30 years-old. The skin area to be evaluated was then cleaned with cotton embedded in alcohol $70 \%$ and the PA signal was measured in the inner and outer faces of both forearms.

Statistical analysis was performed with the software GraphPad Instat ${ }^{\mathbb{B}}$.

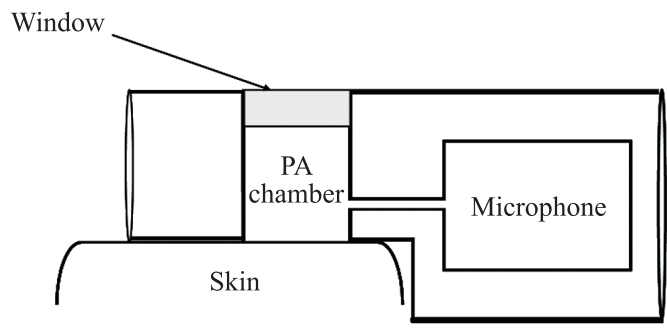

Figure 1. Scheme (cross section) of the double faced PA cell employed in the experiment (developed at UNIVAP).

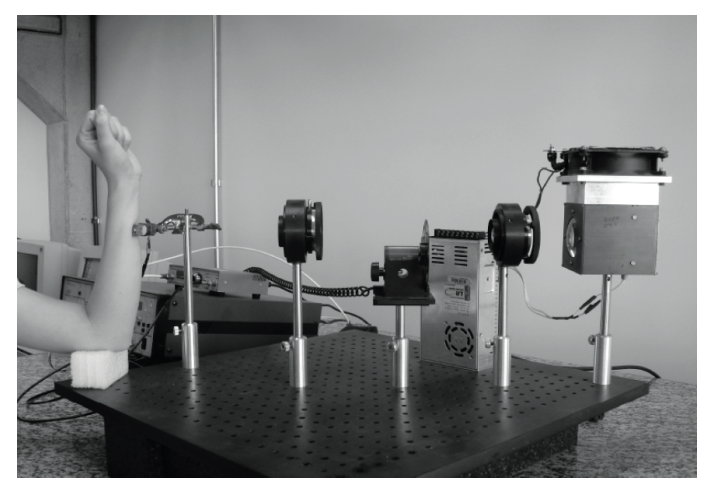

Figure 2. Experimental setup with volunteer positioned for measurement.

\section{Skin type classification}

All the volunteers answered the Fitzpatrick Skin Type questionnaire (Arpansa, 2012), according to which they were classified following the skin phototype system. After PA measurements, volunteers were divided in two groups, pigmented (P) or non-pigmented (NP), following the new skin typing system proposed by Baumann (2006a).

\section{Results}

Volunteers were classified according to the respective skin phototypes. Table 1 presents the average PA amplitude levels (in $\mathrm{mV}$ ) for each phototype.

Comparison between the inner and outer faces of the forearm (paired $t$ test) shows a highly significant difference $(\mathrm{p}<0.005)$, demonstrating the clear influence of sun exposition in skin pigmentation. This is particularly important in Brazil, where UV levels are usually high - in São José dos Campos, where measurements took place, the UV level is normally between 11 and 12 (clear sky) most of the year (INPE, 2012). The ANOVA (parametric) test was applied (see Table 1), showing differences among groups; particularly, PA signal amplitude for the inner face shows a rising tendency as one goes from phototypes II to $\mathrm{V}(\mathrm{p}=0.009)$. 
Table 1. PA signal level $(\mathrm{mV})$ for each skin phototype (average \pm standard deviation). Different indexes (a, b, c, d) indicate significant differences ( $\mathrm{p}<0.05$, ANOVA test).

\begin{tabular}{cccc}
\hline $\begin{array}{c}\text { Skin } \\
\text { phototype }\end{array}$ & N & $\begin{array}{c}\text { Inner face (PA } \\
\text { signal, mV) }\end{array}$ & $\begin{array}{c}\text { Outer face (PA } \\
\text { signal, mV) }\end{array}$ \\
\hline II & 14 & $1.26 \pm 0.05^{\mathrm{a}}$ & $2.6 \pm 0.1^{\mathrm{c}}$ \\
III & 22 & $1.59 \pm 0.09^{\mathrm{ab}}$ & $2.6 \pm 0.1^{\mathrm{c}}$ \\
IV & 16 & $1.7 \pm 0.1^{\mathrm{ab}}$ & $3.2 \pm 0.3^{\mathrm{d}}$ \\
V & 5 & $1.8 \pm 0.1^{\mathrm{b}}$ & $2.9 \pm 0.4^{\mathrm{cd}}$ \\
\hline
\end{tabular}

Comparison among groups (parametric ANOVA): $\mathrm{p}=0.009$ (inner face); $\mathrm{p}=0.022$ (outer face).

Volunteers were then divided in two groups, pigmented (P) or non-pigmented (NP), according to their PA signal amplitude for the inner face of the forearm. As the average value obtained for the whole group of volunteers was $1.5 \mathrm{mV}$ (for inner face skin measurement), this was the cutoff value for separating the volunteers in two groups: "P" for PA signal amplitude above $1.5 \mathrm{mV}$; "NP", under $1.5 \mathrm{mV}$.

This classification follows that recently proposed by Baumann (2006a, 2006b), with the division of volunteers in NP (people with low melanin production) and $\mathrm{P}$ (with significative melanin production). This classification is more influenced by facultative than constitutive factors; in this way, persons from the same family, but with different habits (especially in respect to the level of sun exposure) may appear in different groups. Tables 2 and 3 show the composition of these groups in terms of the phototypes proposed by Fitzpatrick. Table 4 presents the distribution of the volunteers of each phototype in the P and NP groups.

The NP group is composed by volunteers of phototypes II and III, but also includes phototype IV individuals and an isolated case of phototype $\mathrm{V}$ (which declared no sun exposition). Phototype II is the most common in this group; median corresponds to phototype III. Two volunteers of the phototype IV in this group are smokers, who tend to present pale skin, because nicotine destroys collagen fibers and diminishes skin humidity. The $\mathrm{P}$ group is composed by volunteers of phototypes III to V (IV is the median); the only volunteer of phototype II in this group declared daily exposition to sun for 30 minutes.

It is important to observe that few individuals were classified in the group V; hence, observations on the behavior/distribution of this group are qualitative, due to the low sampling.

Table 4 shows that phototype II is highly related to the NP group, while phototypes IV and V concentrate in the P group. Phototype III is found in both groups, showing the variability of elements inside the same phototype classification. Chi-square test was performed with the absolute values corresponding to the data in Table 4 (group $\mathrm{V}$ was excluded due to the low
Table 2. Composition of the NP group.

\begin{tabular}{ccc}
\hline Phototype & Frequency $(\mathbf{n})$ & $\boldsymbol{f}(\boldsymbol{\%})$ \\
\hline II & 13 & 44.9 \\
III & 10 & 34.5 \\
IV & 5 & 17.2 \\
V & 1 & 3.4 \\
Total & 29 & 100.0 \\
\hline
\end{tabular}

Table 3. Composition of the $\mathrm{P}$ group.

\begin{tabular}{ccc}
\hline Phototype & Frequency (n) & $\boldsymbol{f ( \% )}$ \\
\hline II & 1 & 3.6 \\
III & 12 & 42.8 \\
IV & 11 & 39.3 \\
V & 4 & 14.3 \\
Total & 28 & 100.0 \\
\hline
\end{tabular}

Table 4. Distribution of the volunteers of each phototype in the NP and $\mathrm{P}$ groups.

\begin{tabular}{ccc}
\hline Phototype & NP group (\%) & P group (\%) \\
\hline II & 92.9 & 7.1 \\
III & 45.5 & 54.5 \\
IV & 31.2 & 68.8 \\
V & 20.0 & 80.0 \\
\hline
\end{tabular}

$\chi^{2}$ test (excluding group $\mathrm{V}$, due to low sampling): $\mathrm{p}<0.0001$.

sampling); the result, $\mathrm{p}<0.0001$, shows the statistical relationship between the Fitzpatrick classification and the Baumann system.

\section{Discussion}

Recently, the PA technique has been employed in the characterization of products topically applied to the skin (Rossi et al., 2008) and a new methodology, based in PA measurements, was proposed for the determination of the SPF (sun protection factor) for commercially available sunscreens (Oliveira et al., 2008). The present work shows the contribution of this technique in the characterization of human skin, as it was performed before with sunscreens. We emphasize that the PA method presented here comprehends simple, fast in vivo measurements; additionally, this is a quantitative method that substitutes visual inspection (which is undoubtedly subjective).

In this way, the present study opens the possibility for the adoption of this new experimental methodology for the objective classification of skin type.

\section{Conclusion}

This work shows that photoacoustic measurements in vivo are able to detect alterations in skin pigmentation due to sun exposure; this was observed 
in the comparison between inner forearm and outer forearm for all the volunteers that took part in this work. Furthermore, in skin regions normally protected from sun exposure, the PA signal level tends to follow Fitzpatrick classification, also allowing the division of the volunteers in two groups (P and NP), according to their pigmentation levels. Our work shows that the PA technique can provide a simple, direct tool for skin classification, presenting the potential to contribute significantly in this research field. Although the PA signal, at the present stage of research, seems to be better suited to the proposed Baumann classification, our results indicate good prospects for the correlation with Fitzpatrick in future studies, which should use more volunteers. Future research in this field must also focus in the determination of the skin oiliness level through similar experimental methods.

\section{Acknowledgement}

P.R.B. acknowledges the Brazilian agencies FAPESP (04/02193-1) and CNPq (313963/2009-6) for the financial support.

\section{References}

Arkin M, Kubota R, Kanazawa M, Aizawa K. Observation of hemoglobin spectra on epidermis surface using a 2-dimensional spectrum and image analyzer system. Journal of the Tokyo Medical University. 2004; 62(5):523-31.

Australian Radiation Protection and Nuclear Safety Agency - ARPANSA. Skin photo type response examples. [Internet]. [cited 2012 Jan 27]. Available from: http://www. arpansa.gov.au/RadiationProtection/Solaria/Offline/05/07. html.

Barja PR, Acosta-Avalos D, Rompe PCB, Dos Anjos FH, Marciano FR, Da Silva MD. In vivo evaluation of drug delivery after ultrasound aplication: A new use for the photoacoustic technique. Journal de Physique IV, France. 2005; 125:789-91. http://dx.doi.org/10.1051/ jp4:2005125182

Braunwald FA, Isselbacher KJ. Medicina interna. 14 ${ }^{\mathrm{a}}$ ed. Rio de Janeiro: McGraw-Hill; 1998. 1190 p.

Baumann L. New skin typing system. Skin \& Aging. 2006a; 14(2):60-4.

Baumann L. The skin type solution. New York: Beauty e Groming Bantam Hardcover; 2006b. 515p.

Bernengo JC, Gasquez C, Falson-Rieg F. Photoacoustics as a tool for cutaneous permeation studies. High Temperatures-High Pressures. 1988; 30(5):619-24. http:// dx.doi.org/10.1068/htec613

Cahen D.; Bults G.; Garty H.; Malkin, S. Photoacoustic in life sciences. Journal of Biochemical Biophysical Methods. 1980; 3(5):293-310. http://dx.doi.org/10.1016/0165022X(80)90010-X
Carvalho JLC, Devecchi AS, Paiva RF, Barja PR. Goniômetro para medidas em pele humana. In: IX EPG/UNIVAP: Anais do $9^{\circ}$ Encontro Latino Americano de Pós-Graduação da Universidade do Vale do Paraíba; 2009; São José dos Campos. São José dos Campos: UNIVAP; 2009. p. 1-5. CD-ROM.

Diffey BL. Sunscreens and UVA protection: a major issue of minor importance. Journal of Photochemistry and Photobiology. 2001; 74(1):61-3.

Giacomoni PU. Open questions in photobiology III. Melanin and photoprotection. Journal of Photochemistry and Photobiology B: Biology. 1995; 29(1):87-9. http:// dx.doi.org/10.1016/1011-1344(95)90265-1

Gonchoroski DD, Corrêa GM. Tratamento de hipercromia pós-inflamatória com diferentes formulações clareadoras. Infarma. 2005; 17(3-4):84-8.

Instituto Nacional de Pesquisas Espaciais - INPE. Radiação ultravioleta. [Internet]. [acesso em 27 jan. 2012]. Available from: http://satelite.cptec.inpe.br/uv.

Kawada A. Risk and preventive factors for skin phototype. Journal of Dermatological Science. 2000; 23(1):S27-9. http:// dx.doi.org/10.1016/S0923-1811(99)00074-2

Marquezini MV, Cella N, Mansanares AM, Vargas H, Miranda LCM. Open photoacoustic cell spectroscopy. Measurement Science \& Technology. 1991; 2:396-401. http://dx.doi.org/10.1088/0957-0233/2/4/020

Nicoletti M, Orsine EMA, Duarte ACN, Buono GA. Hipercromias: aspectos gerais e uso de despigmentantes cutâneos Cosmetics \& Toiletries. 2002; 14(3):46-53, 2002.

Oliveira SL, Mansanares AM, Silva EC, Barja PR. In vitro determination of the sun protection factor of sunscreens through photoacoustic spectroscopy: A new approach. European Physical Journal ST. 2008; 153:475-8. http:// dx.doi.org/10.1140/epjst/e2008-00488-2

Paiva RF, Barja PR. Células fotoacústicas para medidas em materiais biológicos: projetos e aplicações. In: EHWC'2006: Proceedings of the 1st Environmental and Health World Congress - EHWC; 2006 Julho 16-19; Santos. Santos; 2006. p. 332-5.

Rompe PCB, Dos Anjos FH, Mansanares AM, Silva EC, Acosta-Avalos D, Barja PR. Characterization of human skin through photoacoustic spectroscopy. Journal de Physique IV, França. 2005; 125:785-7, 2005.

Rosencwaig A, Gersho A. Theory of the photoacoustic effect with solids. Journal of Applied Physics. 1976, 47(1):64-9. http://dx.doi.org/10.1063/1.322296

Rossi RCP, Paiva RF, Da Silva MD, Barja PR. Photoacoustic study of percutaneous absorption of Carbopol and transdermic gels for topic use in skin. European Physical Journal ST. 2008; 153:479-82. http://dx.doi.org/10.1140/epjst/ e2008-00489-1

Sousa JM, Avalos DA, Barja PR. Classificação in vivo de tipos de pele por fotoacústica. In: Encontro Latino Americano de Iniciação Científica: Anais de Resumo do V Encontro Latino Americano de Iniciação Científica; 2005; São José dos Campos. São José dos Campos: UNIVAP; 2005. p. 269-72. 
Swearingen JA, Holan SH, Feldman MM, Viator JA. Photoacoustic discrimination of vascular and pigmented lesions using classical and Bayesian methods. Journal of Biomedical Optics. 2010; 15(1):016019. PMid:20210465 PMCid:2917464. http://dx.doi.org/10.1117/1.3316297

Taube TP, Puzzi MB, Rehder J, Mansanares AM, Da Silva EC, Acosta-Avalos D, Barja PR. Characterization of reconstructed human skin using Photoacoustic Spectroscopy. European Physical Journal ST. 2008; 153:471-4. http:// dx.doi.org/10.1140/epjst/e2008-00487-3
Viator JA, Komadina J, Svaasand LO, Aguilar G, Choi B, Stuart Nelson J. A comparative study of photoacoustic and reflectance methods for determination of epidermal melanin content. Jornal of Investigative Dermatology. 2004; 122(6):1432-9. PMid:15175034. http:// dx.doi.org/10.1111/j.0022-202X.2004.22610.x

Viglioglia PA. Biologia cutânea da pele normal. In: Viglioglia PA, Rubin J. Cosmiatria II. 2nd ed. Buenos Aires: AP Americana; 1991. p. 22-37.

\section{Authors}

Jociely Parrilha Mota, Jorge Luis Costa Carvalho, Paulo Roxo Barja*

Instituto de Pesquisa e Desenvolvimento - IP\&D, Universidade do Vale do Paraíba - UNIVAP,

Av. Shishima Hifumi, 2911, Urbanova, CEP 12244-000, São José dos Campos, SP, Brasil. 